\title{
Geomorphic studies for identification of active fault: observations from smaller river basins, South India
}

\author{
Yogendra Singh and Biju John \\ National Institute of Rock Mechanics \\ Kolar Gold Fields, India \\ lamyans.yogendra@gmail.com
}

\author{
GP Ganapathy \\ Vellore Institute of Technology University \\ Vellore, India \\ director.cdmm@vit.ac.in
}

\begin{abstract}
The term active tectonics refers to those processes that produce deformation of earth's crust on a time scale of significance to human society. Earthquakes are the resultants of such deformations at the earth crust. The devastating events occurred in the past three decades (e. g 1993 Killari, 1997 Jabalpur and 2001 Bhuj) has changed the concept of stability of peninsular India. Due to the long reoccurrence interval of damaging earthquakes in Peninsular India, many of the active faults have not shown any seismic activity in the human memory. Since there exist a fast rate of erosion compared to tectonic movement, it becomes very difficult to identify such seismogenic feature. Thus the study of landforms, geomorphic indices and morphometric analysis will play a vital role in identification of subtle deformations associated with such seismogenic features.
\end{abstract}

The study area covers the basins of Vaddakancheripuzha, Karuvannur river and their tributaries. The area has experienced an event of Mw 6.0 (Coimbtore, 1900) in the past. In the present also this area is experiencing micro seismic activity since 1989. In this study effort has been made to identify subtle deformations associated with active tectonic features using the remote sensing, geomorphic and morphometric analysis. Remote sensing study has identified the NW-SE, NE-SW, E-W and NNW-SSE trending lineaments in which the Periyar lineament is identified as three parallel NW-SE trending lineaments. Some other lineaments have also been identified, apparently branched from NW-SE trending Idamalayar lineament.. Valley floor Valley width ratio along the NW-SE trending drainage segments also shows relatively low values $(0.32$ to 10.0$)$ in comparison to $\mathrm{NE}-\mathrm{SW}$ trending drainage segments. Mountain front sinuosity also shows relatively high values along the NW-SE compare to NE-SW trending mountain fronts. In addition to that field studies have also identified NW-SE trending faults in the form of deformation around the areas where the anomalies in geomorphic analysis has been identified. Thus the present study has identified neotectonically induced geomorphological changes associated with the segments of NW-SE lineaments which can be a source for a future seismic event and also first step in the direction of seismic hazard assessment.

Keywords-earthquake; geomorphic marker; drainages; lineaments; neotectonic

\section{INTRODUCTION}

Tectonic geomorphology involves the study of (i) the impact of tectonic base level fall on the processes and morphologies of fluvial systems and (ii) assessment of the relative degrees of tectonic activity of mountain fronts, or other structural elements, during the Quaternary Period [1]. Morphotectonic indices are very sensitive to the climate change, resistance of the basement rock, tectonic process resulting into landscape evolution. Thus the analysis of active structures can be done by using morphotectonic indices.

Review of literature shows some of the earlier studies identified signatures of active tectonism in Peninsular India [13, 19, 32, 33]. Remote sensing technique forms an important tool to identify signatures of active tectonics (e.g. [21]. Over the years it is found that geomorphic studies are helpful in detecting signatures of active tectonism in cratonic interiors $[1,5,12]$. The present study focuses on identifying the active tectonic features from an area of ongoing activity through different morphometric analysis.

The present study is an attempt to identify the signatures of active tectonics evidences of active tectonic signatures, using geomorphic and morphometric analysis as a tool. Historical seismic records of this area are showing that occasional micro tremors are occurring in this region near around Desamangalam since 1989 [11]. The maximum magnitude observed $\left(\mathrm{M}_{\mathrm{L}}=4.3\right)$ during 1994 Wadakkancheri earthquake. The study discusses the anomalous variations of morphometric parameters related with active tectonics in the study region. This study can be used as an indicator for the identification of active faults in similar tectonic setup.

\section{TECTONICS}

Southern Granulite terrain is characterized by Moyar bhavani, Palghat Cauvery and Achankovil shear zones etc. [7]. The study area is falling in south Palghat Cauvery shear zone, one of the major shear zones of peninsular India. The region of ongoing microseismic activity falls in the southern flank of the palghat gap, a conspicuous geomorphic feature associated with Palghat -Cauvery shear zone,in the western Ghats.The only break in this lowland extending from Palghat to the Cauvery delta is controlled by a zone of E-W striking planar tectonic fabrics [7]. An E-W trending gravity high also coincides with the Gap, while the charnockite hills on either side are characterised by a strong negative anomaly [31, 17]. A recent study identified a shear zone along Painavu and Trichur called Karur-Kamban-PainavuTrichur shear zone. Periyar fault identified in the SEISAT follows this shear zone. In another study Desamangalam 
fault was identified which located in the northern part of the study area [11].

\section{GEOLOGY}

In the study area Charnockite massifs dominating the northern hill ranges bounding the Palghat gap, and those in south are mostly composed of a variable suit of charnockite gneiss and pink granitic gneiss [22]. Even though the charnockite are appearing massive in quick observation it shows considerable joints and well developed south dipping foliation in detailed observation. Younger intrusive granites, syenites, some basic rocks and dolerite and gabbro dykes are observed in this area. The granite bodies generally occur as fault or lineament controlled plutons emplaced between 500 to $700 \mathrm{Ma}$ ago [26]. Dolerite and gabbro dykes related to Deccan volcanisms are cutting across the crystalline rocks trending NNW - SSE and WNW - ESE are observed in the region. The emplacement of these basic dykes is controlling the NW-SE lineament patterns $[18,14]$.

The rocks are extensively lateritised in the midland region masking the underlying features. Tertiary and Quarternary formations are seen in the coastal strip. Coastal sands of different colors, mostly brown and white are seen along the coast of the study area. They are occurred as fringes of parallel sand bars, sandy flats and laccustrine deposits. Alluvium is restricted in the river channels and flood planes in the north-western sector.

\section{STUDY AREA}

The study area lies in the southern flank of the Plaghat Gap in the Kerala state of India (Fig. 1). The study area lies between latitude $10^{\circ} 15^{\prime} \mathrm{N}$ and $10^{\circ} 45^{\prime} \mathrm{N}$ and longitude $76^{\circ}$ $0^{\prime} \mathrm{E}$ and $76^{\circ} 30^{\prime} \mathrm{E}$ covering $2300 \mathrm{sq} \mathrm{km}$ on land. The general topography of the area shows the big hills trending NW-SE are lying in the South east part of the study area. As moving from east to west towards the Arabian sea flat lands exists with the gradual slope towards sea.

In the North it is bounded by the Bahrthapuzha river while in the west the Arabian sea exists. As per the seismicity Coimbatore (1900) earth quake is the biggest event around the study area. The southern part of the Bharthapuzha River is also experiencing t he microseismic activities since 1989 and these activities are still continuing there (Fig. 2). The biggest event $\mathrm{M}=3.8$ occurred on 19.07.2012 near Tannikulam, as recorded in Peechi observatory. Many such local events are plotted with the help of single seismological observatory located at Peechi (Fig. 2).

Topographic maps of this area show that Bharthapuzha is the only major river flowing here along with some small river in the southern part. Earlier studies suggest that a NWSE trending Desamangalam fault of reverse nature has affected the course of Bharthapuzha river from N-S to NW$\mathrm{SE}$ [12]. While other small rivers trending viz NW- SE (Mangalam puzha and Gayathripuza), NE-SW (Vadakkancheripuzha), and E-W (Bharathpuzha), NE-SW (Manali river), E-W (Karuvannur River), E-W
(Kurumalipuzha), E-W (Chalakudi River) are also falling in the area.

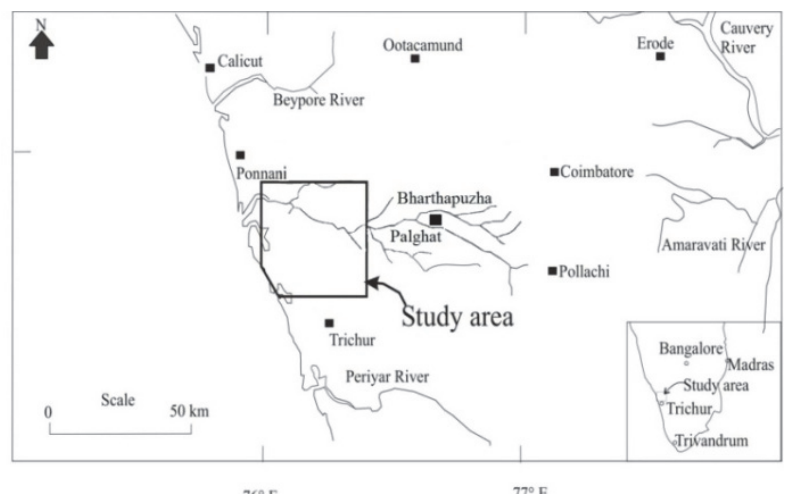

1. Location of the Study Area

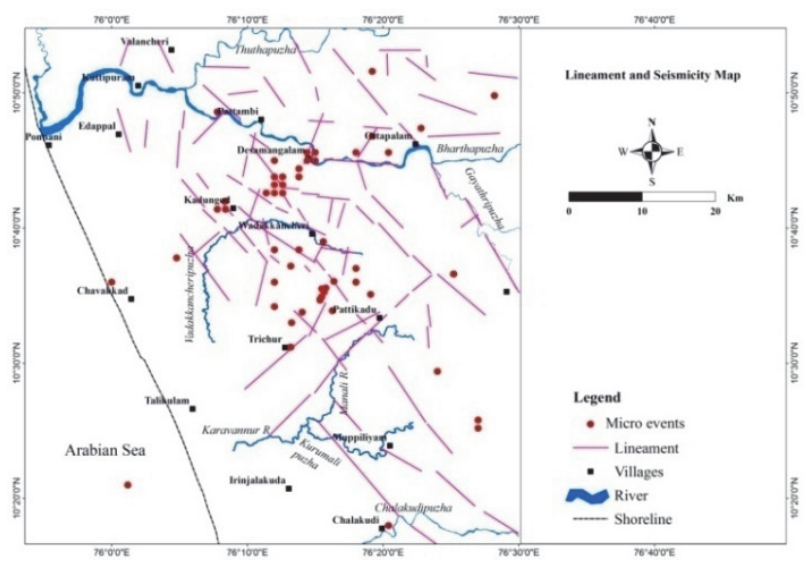

Fig. 2. Lineament and Seismicity map of the study area

\section{Methodology}

In the present study topographic map of SOI, scale 1:50,000 and the multispectral Landsat images have been utilized for the delineation of the lineament. Drainage network of the area have been extracted from the topographic maps. This drainage network is further cross checked with the satellite images.

The delineation of the lineaments (Fig. 2), identification of anomalies in the drainage network has been done through visual interpretation of Landsat as well as toposheets. For the qualitative and quantitative analysis of the drainage network the area has been divided into 138 sub basin taking the third and fourth order drainage in consideration (Fig. 3). Anomalies indentified in the drainage system and their with the lineaments is demarcated to analyze the influence of the lineaments in the drainage system. Several parameters have been calculated i.e Basin Elongation Ratio, Topographic Symmetry Factor(T), Asymmetry Factor (AF), Valley Floor to Valley Width Ratio (Vf), Mountain front sinuosity(Smf), which has been used by many researchers throughout the globe for the identification of the tectonic activities $[1,28$, $9,27,34,23,6,16,15,2,3,29,24]$. In the present study also the qualitative and quantitative analysis of the above said morphometric and geomorphic indices have been done for the assessment of ongoing tectonic activity. 


\section{GEOMORPHIC AND MORPHOMETIC PARAMETRES}

Various studies done throughout the globe by various researchers has documented through their work that the changes in geomorphology such as change in landscape, evolution of fluvial system induced due to the tectonic activities can be identified with the careful study of geomorphic features and indices. The geomorphic features and indices are such as Valley floor/Valley width ratio (Vf), Mountain front sinuosity (Smf), etc $[1,28,9,27,34,23,6$, $16,15,2,3,29,24]$.

As discussed above study of various geomorphic indices given by Bull and McFadden [1] has been widely used and tested throughout the globe by many researchers in the tectonically active area e.g SW USA [1, 25], Costa Rica [34], Oregon Coast Range, USA [23,] the Kachchh region, India [30], southeast Spain [29] and western Taiwan [4]. In the present study also, an attempt have been made to identify any subtle deformation associated with tectonics using the following geomorphic indices. In the present study, the area has been divided into 138 sub basins. The parameter listed in Table I has been utilized for the qualitative and quantitative analysis.

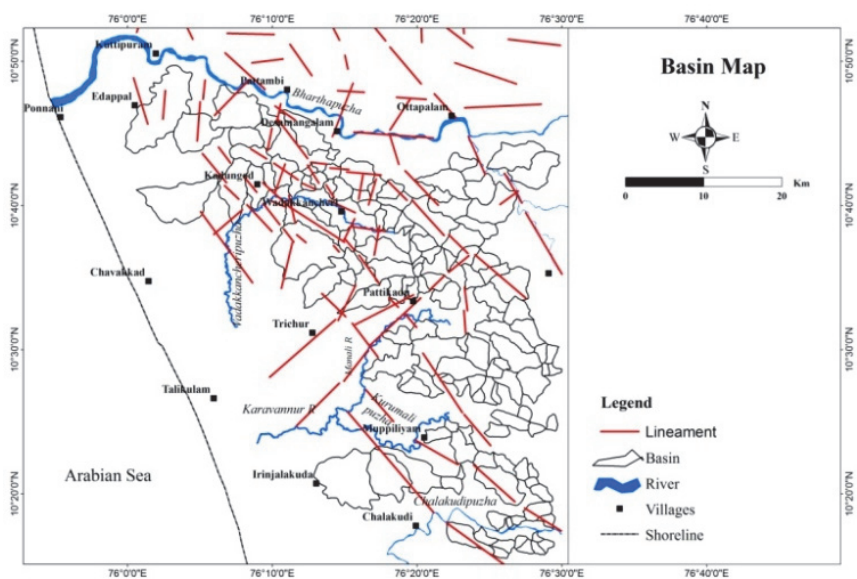

Fig. 3. Map representing the delineated 138 sub basins.

\section{A. Valley Floor Valley Height Ratio}

Subsequent studies were done in the southern part of the Bharthapuzha river. Through the remote sensing and topographic map studies it is found there a network of interconnected drainages is existing there. Some drainage are converted into the cultivated lands and some are still active. In some of the location viz Kadavallur, Chalissery, Peringod both dry and active channels are field checked also (Fig.4.).

The major directions of the drainages are N-S, NW-SE and NE-SW. Using the remotes sensing and the field data all the interconnected drainages seen in the north west part of the study area was mapped (Fig.5). For the better understanding of the drainage system in context with the tectonics valley floor width to valley height $\left(\mathrm{V}_{\mathrm{f}}\right)$ ratio was calculated.
TABle I.COMPUTED MORPHOTECTONIC PARAMETERS WITH THEIR VALUES FOR THE STUDY AREA.

\begin{tabular}{|c|c|c|}
\hline $\begin{array}{l}\text { Morphotectonic } \\
\text { Parameters and Formula }\end{array}$ & Values, Inferences & $\begin{array}{l}\text { Range } \\
\text { in } \\
\text { Study } \\
\text { Area }\end{array}$ \\
\hline \multirow{2}{*}{$\begin{array}{l}\text { Basin Elongation Ratio (Re) } \\
\operatorname{Re}=(2 \sqrt{ } \mathrm{A} / \sqrt{ } \Pi) / \mathrm{L}, \quad \mathrm{A}=\mathrm{Basin} \\
\text { area, } \mathrm{L}=\text { Basin Length }\end{array}$} & $\begin{array}{l}\operatorname{Re}<0.50, \quad \text { Tectonically } \\
\text { Active }\end{array}$ & \multirow{3}{*}{0.672} \\
\hline & $\begin{array}{l}\mathrm{Re}=0.50-0.75, \text { Slightly } \\
\text { Active }\end{array}$ & \\
\hline Bull \& Mc Fadden (1977) & $\begin{array}{l}\mathrm{Re}>0.75, \quad \text { Inactive } \\
\text { settings }\end{array}$ & \\
\hline $\begin{array}{l}\text { Topographic Symmetry } \\
\text { Factor(T) } \\
\mathrm{T}=\mathrm{Da} / \mathrm{Dd} \text {, } \\
\text { Where Da=Distance from } \\
\text { midline of drainage basin to } \\
\text { midline of active channel and } \\
\text { Dd = Distance from basin } \\
\text { midline to basin divide. } \\
\text { Cox (1994) }\end{array}$ & $\mathrm{T}=0$, Symmetric Basin & \multirow{3}{*}{$\begin{array}{l}0.3- \\
0.8\end{array}$} \\
\hline \multirow{2}{*}{$\begin{array}{l}\mathrm{T}=\mathrm{Da} / \mathrm{Dd} \text {, } \\
\text { Where } \mathrm{Da}=\text { Distance from } \\
\text { midline of drainage basin to } \\
\text { midline of active channel and } \\
\mathrm{Dd}=\text { Distance from basin } \\
\text { midline to basin divide. }\end{array}$} & & \\
\hline & $\mathrm{T}>0$, Asymmetric Basin & \\
\hline \multirow[t]{2}{*}{$\begin{array}{l}\text { Asymmetry Factor }(\mathrm{AF}) \\
\mathrm{AF}=100(\mathrm{Ar} / \mathrm{At}) \text {, where } \mathrm{Ar}= \\
\text { Right hand side area of } \\
\text { drainage looking downstream } \\
\text { and At }=\text { Total area of drainage } \\
\text { Basin }\end{array}$} & $\begin{array}{l}\mathrm{AF}=50, \text { Stable Setting } \\
\text { Environment }\end{array}$ & \multirow[t]{2}{*}{63.84} \\
\hline & $\begin{array}{l}\text { AF }>\text { or }<50, \quad \text { Suggest } \\
\text { Tilt }\end{array}$ & \\
\hline \multirow{2}{*}{$\begin{array}{l}\text { Valley Floor to Valley Width } \\
\text { Ratio (Vf) } \\
\text { Vf }=2 \text { Vfw/I(Eld-Esc) }+ \text { (Erd- } \\
\text { Esc) I, where Vfw }=\text { Width of } \\
\text { valley floor, Eld \& Erd = } \\
\text { Elevation of the left \& right } \\
\text { valley divides respectively and } \\
\text { Esc = Elevation of valley floor } \\
\text { Bull \& Mc Fadden (1977) }\end{array}$} & $\begin{array}{l}\text { Low Values, Deep } \\
\text { Valleys, } \\
\text { Active Incision }\end{array}$ & \multirow[t]{2}{*}{$\begin{array}{l}0.32- \\
14.38\end{array}$} \\
\hline & $\begin{array}{l}\text { High Values, Broad } \\
\text { Valleys }\end{array}$ & \\
\hline $\begin{array}{l}\text { Mountain front sinuosity } \\
(\mathrm{Smf}) \\
\mathrm{Smf}=\mathrm{Lmf} / \mathrm{Ls} \text { where, } \mathrm{Smf}= \\
\text { mountain-front sinuosity, } \mathrm{Lmf}= \\
\text { is the length of the mountain } \\
\text { front and Ls = chord length or } \\
\text { straight line length. } \\
\text { Bull and McFadden } \\
(1977)\end{array}$ & $\begin{array}{l}\text { Smf }=1.0-1.6, \text { Most } \\
\text { active mountain fronts } \\
\text { those associated with } \\
\text { active range bounding } \\
\text { faults. } \\
\text { Smf }=1.4-3.0 \text {, Mountain } \\
\text { fronts with lesser activity } \\
\text { but still reflecting active } \\
\text { tectonics } \\
\text { Smf }=1.8 \text { to }>5 \text {, Inactive } \\
\text { mountains }\end{array}$ & $\begin{array}{l}1.11- \\
2.42\end{array}$ \\
\hline
\end{tabular}

The ratio of the width of valley floor to valley height $V_{f}$ may is defined as

$$
\mathrm{V}_{\mathrm{f}}=2 \mathrm{~V}_{\mathrm{fw}} /\left[\left(\mathrm{E}_{\mathrm{ld}}-\mathrm{E}_{\mathrm{sc}}\right)+\left(\mathrm{E}_{\mathrm{rd}}-\mathrm{E}_{\mathrm{sc}}\right)\right]
$$

where $V_{f w}$ is the width of valley floor, $E_{l d}$ and $E_{r d}$ are the respective elevations of the left and right valley divides, and 


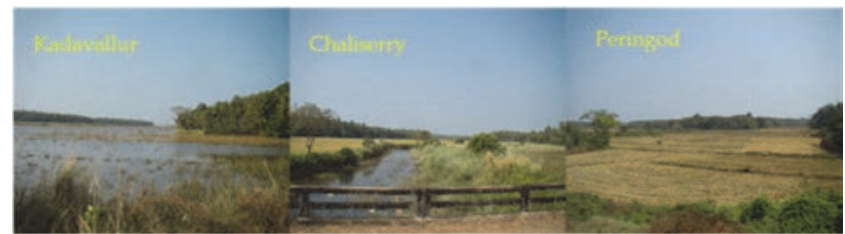

Fig.4: View of identified dry and active paleochannel in the study area

$\mathrm{E}_{\mathrm{sc}}$, is the elevation of the valley floor [1]. In determining $\mathrm{V}_{\mathrm{f}}$ the data are measured at a given distance up from the mountain front. The ratio was calculated at about 27 locations in the study area along the active streams and the identified paleochannels. The results show that broadfloored valleys and narrow valley are seen in both NW-SE and NE-SW direction. As the drainages are approaching to the Arabian sea, almost flat lands are there and the values of $\mathrm{V}_{\mathrm{f}}$ has increased but still it is low in the little higher area. The value of $V_{f}$ varies from 0.32 to 14.38 . It is observed that the lower values of the ratio are mainly associated along the NW-SE trending valleys. While higher values are observed alond the NE-SW trending valleys, by at places in the central part of the study area NE SW trending valleys are also showing low values. Majority of the NW-SE trendingvalley are foundalong the NW-SE trending lineaments. Which indicates the active incision is more vigorous along NW-SE trending valleys in comparison to the NE-SW valleys. Since the lower values of the ratio are indicative of the ongoing tectonic activities, thus the present data may indicate that the tectonic activities are more vigorous along the NW-SE trending valley[8].

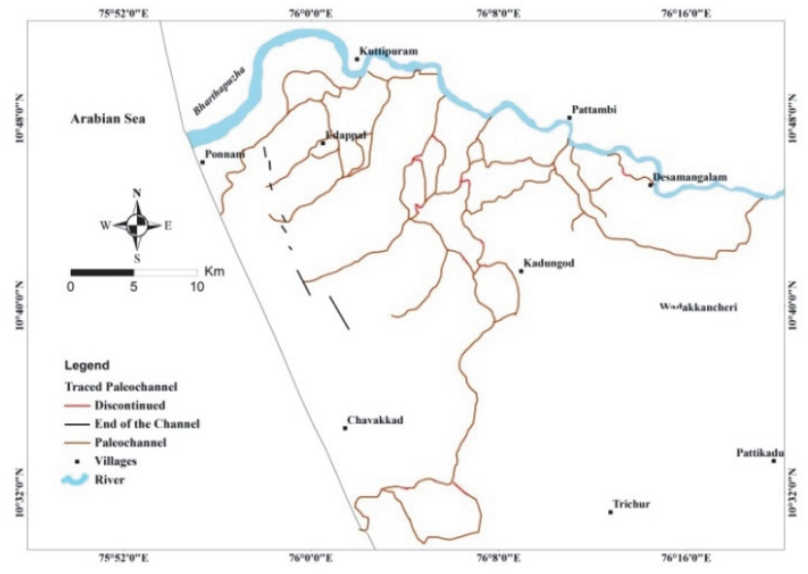

Fig. 5.. Network of interconnected drainages in study area.

\section{B. Mountain Front Sinousity}

Mountain-front sinuosity $\left(\mathrm{S}_{\mathrm{mf}}\right)$ is defined as

$$
\mathrm{S}_{\mathrm{mf}}=\mathrm{L}_{\mathrm{mf}} / \mathrm{L}_{\mathrm{s}}
$$

where $\mathrm{L}_{\mathrm{mf}}$ is the length of mountain front along the mountain-piedmont (foot of mountain) junction and $L_{s}$ is the straight-line length of the front. The $\mathrm{S}_{\mathrm{mf}}$ index reflects a balance between the tendency of streams and slope processes to produce an irregular (sinuous) mountain front and vertical active tectonics that tends to produce a prominent straight front [1]. Mountain front sinuosity is a balance between the tendency of uplift to maintain a fairly straight front that coincides with a tectonic structure and the work of streams that tend to erode irregularities into the front [1]. In the study area nearly all the mountain fronts are trending NW-SE direction except few tending in NE-SW direction.

Based on the previous study a classification for the values of the ratio has been given, in relation to the tectonic activities [1]. The classification is as follows:

- $\quad \mathrm{Smf}=1.0-1.6$, Most active mountain fronts those associated with active range bounding faults.

- $\mathrm{Smf}=1.4-3.0$, Mountain fronts with lesser activity but still reflecting active tectonics

- $\quad \mathrm{Smf}=1.8$ to $>5$, Inactive

It is observed that the major trend of the mountain front in the study area is NW-SE and NE-SE. In the present study 33 stretches have been marked along the various mountain fronts for the calculation of mountain front sinuosity.The results are given in Table 2. Mountain front sinuosity of the study area lies between 1.11-2.46. Out of the 33 stretches 14 stretches are are falling in the most active front range. While rest 19 stretches falling in the less activity range. It is observed that the majority of the NW-SE mountain front is showing the lower values of the ratio. It may indicate that the activity is continuing along both the trends but, more vigorous along the NW-SE trending fron in comparison to the NE-SE trending front.

C. Elongation Ratio (Re)

Elongation ratio is represented

$$
\operatorname{Re}=2(\sqrt{ } \mathrm{A} / \sqrt{ } \pi) / \mathrm{L}
$$

Where $\mathrm{A}$ is the area of basing and $\mathrm{L}$ is the length of respective basin [1]. During the investigation 138 basin in the study area were marked (Map 3). The values of the ratio are ranging from 0.43 to 9.8 . In all the values of the ratio it is observed only 9 basins are having values less than 0.5 and falling in the tectonically active range. While 93 basins are having values between 0.5 to 0.75 and coming in the slightly active range. 38 basins are having the value more than 0.75 suggesting that part of the study area as inactive. Since average of all the values of elongation ratio is 0.672 and coming between 0.5 to 0.75 . It is observed that the anomalous values of the ratios are associated along or in the vicinity of the NW-SE trending lineaments. The anomalies observed along NW-SE trending lineaments may indicate the control of NW-SE trending structures within the study area.

\section{Assymetry Factor (Af)}

Asymmetric factor is the ratio existing between the area of the basin to the right (facing downstream) of the trunk stream and the total area of the drainage basin. For a stream network flowing in a stable setting and uniform lithology, the asymmetric factor should be equal to 50 . In all the other cases there will be a change in value to either side of 50 [8]. 
Table II. Mountain Front Sinousity index of Study AREa

\begin{tabular}{|c|c|c|c|}
\hline Segment & $\mathrm{L}_{\mathrm{mf}}(\mathrm{Km})$ & $\mathrm{L}_{\mathrm{s}}(\mathrm{Km})$ & $\mathrm{S}_{\mathrm{mf}}(\mathrm{Km})$ \\
\hline 1 & 4.77 & 10.83 & 2.27 \\
\hline 2 & 4.97 & 9.45 & 1.90 \\
\hline 3 & 7.91 & 18.46 & 2.33 \\
\hline 4 & 3.27 & 3.97 & 1.21 \\
\hline 5 & 5.27 & 8.26 & 1.57 \\
\hline 6 & 9.86 & 20.52 & 2.08 \\
\hline 7 & 5.90 & 11.13 & 1.89 \\
\hline 8 & 5.42 & 9.03 & 1.67 \\
\hline 9 & 2.33 & 3.57 & 1.54 \\
\hline 10 & 6.47 & 10.85 & 1.68 \\
\hline 11 & 6.13 & 13.87 & 2.26 \\
\hline 12 & 6.32 & 11.37 & 1.80 \\
\hline 13 & 5.35 & 13.18 & 2.46 \\
\hline 14 & 4.32 & 7.66 & 1.77 \\
\hline 15 & 11.32 & 17.09 & 1.51 \\
\hline 16 & 8.30 & 20.06 & 2.42 \\
\hline 17 & 5.25 & 8.62 & 1.64 \\
\hline 18 & 5.80 & 9.52 & 1.64 \\
\hline 19 & 3.33 & 3.85 & 1.16 \\
\hline 20 & 1.83 & 2.34 & 1.28 \\
\hline 21 & 2.17 & 2.60 & 1.20 \\
\hline 22 & 5.46 & 6.56 & 1.20 \\
\hline 23 & 3.24 & 3.59 & 1.11 \\
\hline 24 & 3.15 & 7.00 & 2.22 \\
\hline 25 & 4.63 & 6.63 & 1.43 \\
\hline 26 & 3.36 & 6.59 & 1.96 \\
\hline 27 & 3.64 & 7.59 & 2.08 \\
\hline 28 & 2.91 & 3.92 & 1.35 \\
\hline 29 & 2.92 & 4.66 & 1.60 \\
\hline 30 & 2.57 & 4.28 & 1.66 \\
\hline 31 & 3.27 & 4.99 & 1.53 \\
\hline 32 & 3.36 & 4.08 & 1.21 \\
\hline 33 & 3.68 & 6.17 & 1.67 \\
\hline
\end{tabular}

This index is used to detect the tectonic tilt of the basin areas [10]. This quantitative analysis has been done for the 138 sub basins delineated for the $3^{\text {rd }}$ and $4^{\text {th }}$ order drainages (Map 3). The asymmetrical index is determined by using Eq. iv for each basin.

$$
\mathrm{AF}=100(\mathrm{Av} / \mathrm{At})
$$

Where Av is the basin area includes the secondary drainages in the right side of Main River $(\mathrm{km} 2)$, At is the basin area includes the secondary drainages in the left side of main river $(\mathrm{km} 2)$ and $\mathrm{AF}$ is drainage asymmetry index.

In the present study the asymmetry factor have been calculated for 138 sub basins. The value of the ratio is ranging from 12.74 to 84.74 . If it is considered that 45 to 55 is the normal range for the basin tilt within the study area then $39 \%$ of the basin are falling in below 45 category, 39\% are falling in above 55 category. Only $22 \%$ of the basins are falling in the normal range. Majority of the basins are showing tilting that is anomalous, which may indicate the influence of the tectonic structures, with in the study area.

\section{E. Transverse Topographic Symmetry Factor (T): It is represented as}

$$
\mathrm{T}=\mathrm{D}_{\mathrm{a}} / \mathrm{D}_{\mathrm{d}}
$$

Where $\mathrm{Da}$ is the space from the midline of the drainage basin to the midline of the active belt and Dd is the space from the midline to the basin limit [5]. In a completely symmetric basin $\mathrm{T}=0$ and as asymmetry increases $\mathrm{T}$ approaches to value of 1.0. In the present study also the values $\mathrm{T}$ is ranging between 0.03 to 0.8 . It is observed that the basins falling along or in the vicinity of the NW-SE trending lineaments are showing the high values of the ratio. In the qualitative assessment of the tilting of the basins, the higher values of $\mathrm{T}$ may indicate the topographical response of the area to the lying structure with in the study area. The high values of $\mathrm{T}$ may indicate the ongoing tectonic activity in the study area.

\section{VII.CONCLUSION}

Computation of all the geomorphic indices is done by using GIS 9.3 and considered to be suitable for evaluating the effects of active tectonics in the study area. Five geomorphic indices, viz. basin elongation ratio (Re), transverse topographic symmetry $(\mathrm{T})$, asymmetric factor (AF), valley floor width to valley height ratio (Vf), mountain front sinuosity (Smf) have been used for the identify geological tectonic structure with in the study area. Anomalies identified in the $\mathrm{Re}, \mathrm{A} f$ and $\mathrm{T}$ factors may indicate the topographic response of the area to the prevailing structures there in the present tectonic response i.e compressional. The anomalies observed along the linear valley through $\mathrm{V} f$ and the on the mountain front sinuosity ratio gives the direct evidences of the ongoing tectonic activities tough its very feeble. Since 1989 the area is experiencing the microsiesmic activities. Which is an add on the to the deformation observed in the form of anomalies identified in the present study. Majority of the micro seismic events and the anomalies are observed alonf or in the vicinity of the NW-SE trending structure. Thus the present study has identified neotectonically induced geomorphological changes associated with the segments of NW-SE lineaments which can be a source for a future seismic event and also first step in the direction of seismic hazard assessment. A detailed study and monitoring along these structure will help in the proper assessment and potential of these structures. This can be the next step in the direction of the seimic hazard assessment.

\section{REFERENCES}

[1] W.B. Bull and L.D. McFadden, "Tectonic geomorphology north and south of the Garlock fault, California." In: D.O. Doehring (Ed.), Geomorphology in arid regions. Publications in Geomorphology, State University of New York and Binghamton, 1977, pp. 115-138.

[2] D.W. Burbank,R.S. Anderson, “Tectonic Geomorphology.” Blackwell Science, p. 274, 2001.

[3] B. Champel, B.P. van der, J.L. Mugnier, P. Leturmy, "Growth and lateral propagation of fault-related folds in the Siwaliks of western Nepal: Rates, mechanisms, and geomorphic signature." Journal of Geophysical Research,2002, vol. 107 (2111), pp. 12-18.

[4] Y.C. Chen, Q. Sung and K.Y. Cheng, "Along-strike variations of morphotectonic features in the Western Foothills of Taiwan: tectonic 
implications based on stream-gradient and hypsometric analysis." Geomorphology,2003, vol. 56, pp.109-137.

[5] R. T. Cox, "Analysis of drainage basin asymmetry as a rapid technique to identify areas of possible Quaternary tilt-block tectonics: an example from the Mississippi embayment." Geological Society of American Bulletin, 1994, vol.106, pp 571-581.

[6] A. Demoulin, "Testing the tectonic significance of some parameters of longitudinal river profiles: the case of the Ardenne (Belgium, NW Europe)." Geomorphology 1998. vol. 24, pp. 189-208.

[7] S.A. Drury, N.B.W. Harris, R.W. Holt, G. J. Reeves-Smith, and R.T.Wightman, "Precambrian tectonics and crustal evolution of south India.” J. Geol. 1984, vol. 92, pp. 3-20.

[8] A. Edward, Keller., and Nicholas Pinter. "Active Tectonics," Prentice Hall, International (U.K.) limited, London, 1996.

[9] D.I. Gregory, S.A. Schumm, "The effect of active tectonics on alluvial river morphology." In: Richard, K. (Ed.), River Channels: Environments and Processes. Basil Blackwell, Oxford, 1987. pp. 4168.

[10] P. W. Hare, and T. W. Gardner, "Geomorphic indicators of vertical neotectonism along converging plate margins, Nicoya Peninsula, Costa Rica," In: Tectonic Geomorphology: Proceedings of the 15th Annual Binghamton Geomorphology Symposium, (Eds), 1985.

[11] B. John, and C.P. Rajendran, "Evidence of episodic brittle faulting in the cratonic part of the Peninsular India and its implications for seismic hazard in the slow deforming regions." Tectonophysics, 2009, vol. 471, pp. 240-252.

[12] B. John, and C.P. Rajendran, "Geomorphic indicators of neotectonism from the Precambrian terrain of peninsular India- A study from the Bharathapuzha basin, Kerala." Jour. Geol. Soc. India, 2008, vol.71, pp. 827-840.

[13] L.C. King, "Study of world's plain lands: a new approach in Geomorphology." Quaternary Journal, Geological Society of London, 1950, vol.56, pp. 101-131.

[14] V.S. Krishnaswami, "The Deccan volcanic episode; related volcanism and geothermal manifestations." In: Subbarao, K.V., Sukheswala, R.N. (Eds.), Deccan volcanism. Geol. Soc. India Mem., 1981, vol. 3, pp. 1-7.

[15] J.N. Malik, P.S. Sohoni, S.S. Merh andR.V. Karanth, "Active tectonic control on alluvial fan architecture along the Kachchh Mainland Hill Range, Western India." Zeithschrift fu" r Geomorphologie, 2001, vol. 45 (1), pp. 81-100.

[16] J.P. McCalpin, "Paleoseismology." Academic Press, New York, p. 5881996

[17] D.C. Mishra, V.M. Talwari, S.B. Gupta, and V.M.B.S. Rao, "Anomalous mass distribution in the epicentral area of Latur Earthquake," Current science, 1998, vol. 70, pp 385 -390.

[18] M.M. Nair, "Structural trend line patterns and lineaments of the Western Ghats, south of $13^{\circ}$ latitude." J. Geol. Soc. India 1990, vol. 35, pp. 99-105.

[19] B. P. Radhakrishna," Geomorphological approach to the charnockite problem." Journal of Geological Society of India, 1968, vol. 9, pp. 67-74.

[20] C.P. Rajendran andK. Rajendran, "Low-moderate seismicity in the vicinity of Palghat gap, South India and its implications." Curr. Sci., 1996, vol.70, pp 304-307.

[21] S. M. Ramasamy, "Remote Sensing and Active Tectonics of South India," International Journal of Remote Sensing, 2006, vol. 27(20), pp.4397-4431.

[22] G.R. Ravindra Kumar and T. Chacko, "Geothermobarometry of mafic granulites and metapelites from Palghat region of south India: evidence for isothermal uplift and rapid cooling," Journal of Metamorphic Geology, 1994, vol.12,pp. 479-492.

[23] S. Rhea, "Geomorphic observations of rivers in the Oregon Coast Range from a regional reconnaissance perspective." Geomorphology 1993, vol. 6 (2), pp. 135-150.

[24] R. Riquelmea, J. Martinod, G. Herail, J. Darrozesa andR. Charrierb, "A geomorphological approach to determining the Neogene to Recent tectonic deformation in the Coastal Cordillera of northern Chile (Atacama)." Tectonophysics,2003, vol. 361, pp. 255-275.

[25] T.K. Rockwell, E.A., Keller andD.L., Johnson, "Tectonic geomorphology of alluvial fans and mountain fronts near Ventura, California,". In: Morisawa, M., Hack, T.J. (Eds.), Tectonic Geomorphology. Publications in Geomorphology, State University of New York, Binghamton, pp. 183-207, 1984.

[26] M. Santosh, and S.A. Drury, "Alkaligranites with Pan African affinities from Kerala, South India.” Jour.Geol. 1988, vol.98, pp.616626.

[27] S.A. Schumm, J.F. Dumont and M.J. Holbrook, “Active Tectonics and Alluvial Rivers.” Cambridge University Press, Cambridge, p. 276, 2002.

[28] L. Seeber andV. Gornitz, "River profiles along the Himalayan arc as indicators of active tectonics". Tectonophysics, 1983, 92, 335-367.

[28] P.G. Silva, J.L. Goy, C. Zazo andT. Bardaj1, "Fault-generated mountain fronts in southeast Spain: geomorphologic assessment of tectonic and seismic activity." Geomorphology,2003, vol. 50, pp. 203-225.

[29] P.S. Sohoni, J.N. Malik, S.S. Merh andR.V. Karanth, "Active tectonics astride Katrol Hill Zone, Kachchh, Western India." Journal of Geological Society of India 1999, vol. 53, pp.579-586.

[30] C. Subrahamnyam and R.K. Verma, "Gravity fields, structure and tectonics of the eastern ghats," Tectonophysics, 1986, vol. 126, pp.195-212.

[32] R. Vaidyanadhan, "Recent advances in geomorphic studies of peninsular India: A review: Indian." Jour. Earth Sci., 1977, (Ray Volume), pp. 13-35.

[33] K.S. Valdiya, "Late Quaternary movements and landscape rejuvenation in South-Eastern Karnataka and adjoining Tamil Nadu in Southern Indian shield.” Journal Geological Society of India, 1998, vol. 51, pp. 139-166.

[34] S.G. Wells, T.F. Bullard, C.M. Menges, P.G. Drake, P.A. Karas, K.I. Kelson, J.B. Ritter andJ.R. Wesling, "Regional variations in tectonic geomorphology along a segmented convergent plate boundary, Pacific coast of Costa Rica." Geomorphology,1988, vol.1, pp. 239266. 